Int. J. Dev. Biol. 53: 1623-1634 (2009)

doi: $10.1387 / \mathrm{ijdb} .072534 \mathrm{jp}$

\title{
Lessons from a search for leaf mutants in Arabidopsis thaliana
}

\author{
JOSÉ MANUEL PÉREZ-PÉREZ, HÉCTOR CANDELA\#, PEDRO ROBLES, VÍCTOR QUESADA, \\ MARÍA ROSA PONCE and JOSÉ LUIS MICOL*
}

División de Genética and Instituto de Bioingeniería, Universidad Miguel Hernández, Campus de Elche, Elche, Alicante, Spain

\begin{abstract}
Large-scale exploratory approaches to understanding gene function laid the foundations for the "-omics era". Based on modern technologies for the structural and functional characterization of genomes, these curiosity-driven approaches allow systematic accumulation of vast amounts of data, enabling subsequent hypothesis-driven research. Some years before the dawn of genomics, exploratory approaches were already furthering our understanding of gene function in the form of saturation mutagenesis experiments aimed at the identification of all genes that mutate to a given phenotype. Forward genetic approaches, conducted on experimental organisms such as Drosophila melanogaster and Caenorhabditis elegans, have led to the isolation of mutants affected in specific developmental processes, whose cellular and molecular characterization has unraveled the underlying genetic mechanisms of animal development. To shed light on the making of plant leaves, in 1993 we initiated an attempt to identify as many viable and fertile mutants with abnormal leaf morphology as possible, using the Arabidopsis thaliana model organism. We identified 25 fast-neutron- and 153 ethyl-methane sulfonate-induced mutations, which fell into eight and 94 complementation groups, respectively. We also studied 115 publicly available mutant lines isolated by previous authors, which fell into 37 complementation groups. Although we did not reach saturation of the Arabidopsis thaliana genome, the broad spectrum of leaf morphological alterations identified is facilitating the dissection of specific leaf developmental processes. In a complementary approach, we also analyzed leaf architecture in natural accessions and two populations of recombinant inbred lines. Using a high-throughput gene mapping method, we have already cloned 25 of the genes identified by mutation, in some cases in collaboration with other groups. The products of these genes participate in various developmental processes, such as polar cell expansion, transduction of hormonal signals, gene regulation, plastid biogenesis, and chromatin remodeling, among others. The range of phenotypes and processes identified reveal the complexity of leaf ontogeny and will help explain the diversity of leaf morphology in nature.
\end{abstract}

KEY WORDS: Arabidopsis thaliana, forward genetics, leaf development, mutant screen

\begin{abstract}
While walking in the Public Gardens of Palermo, it came to me in a flash that in the organ of the plant which we are accustomed to call the leaf lies the true Proteus who can hide or reveal himself in all vegetal forms. From first to last, the plant is nothing but leaf, which is so inseparable from the future germ that one cannot think of one without the other.
\end{abstract}

Goethe (1816).

\section{Curiosity-driven versus hypothesis-driven research}

The advent of high-throughput, cost-effective techniques for the structural and functional characterization of genomes has led to a revolution in biology. In an unprecedented approach, the emphasis of scientific research is not on the generation and experimental testing of hypotheses, but on the systematic gathering of vast amounts of data (i.e., genome sequences) and the generation of large collections of resources (i.e., tagged mutants, gene libraries), often accessible through publicly available databases. These initial observations provide the starting information

\footnotetext{
*Address correspondence to: José Luis Micol. División de Genética and Instituto de Bioingeniería, Universidad Miguel Hernández, 03202 Elche, Alicante, Spain. e-mail: jlmicol@umh.es

\#Note: Plant Gene Expression Center, 800 Buchanan St., Albany, California 94710, USA
}

Final author-corrected PDF published online: 28 October 2008.

ISSN: Online 1696-3547, Print 0214-6282

() 2009 UBC Press

Printed in Spain 
that enables subsequent hypothesis-driven research, which would be impossible in the absence of any prior knowledge of the process under study. Underlining the fact that no guiding hypothesis is required, this type of research is referred to in various ways, including terms such as exploratory, inductive, observational, data-driven, question-driven, or curiosity-driven. Curiosity-driven approaches are sometimes neglected, even though they have the potential to yield substantial, rather than incremental, advances in knowledge simply because they are not constrained by the limits and expectations imposed by current paradigms. As some authors have highlighted (Kell and Oliver, 2004; Franklin, 2005), curiosity-driven research contributes to the advancement of science more than is usually recognized and is complementary in nature to hypothesis-driven research, since both act as iterative partners in the cycle of knowledge.

Some years before the "-omics era", exploratory approaches were already furthering our understanding of gene function, in the form of large-scale mutagenesis experiments aimed at the identification of mutant alleles for all genes that contribute to a given phenotype (Murray, 2000). The classical example was pioneered by Nüsslein-Volhard and Wieschaus (1980), who devised the methodology for saturation mutagenesis and applied it to the dissection of embryonic development in the model organism Drosophila melanogaster, with no assumption other than that development is under genetic control. Our current understanding of many other important biological phenomena derives from applying the same rationale to many experimental systems. More recently, genomics has provided researchers with a wealth of data from high-throughput array-based experiments (Lockhart and Winzeler, 2000), including global analyses of gene expression under multiple experimental conditions, and from novel massively parallel sequencing techniques (Margulies et al., 2005; Rogers and Venter, 2005), which can be used to obtain direct estimates of the abundance of molecules being sequenced. These techniques are expected to assist in the design of hypotheses that will lead to a mechanistic understanding of the regulatory networks that underlie complex processes, such as the development of multicellular organisms. In this context, the generation of collections of mutants induced by random mutagenesis fulfills the dual objective of providing a survey of the range of phenotypes that can arise after perturbation of the wild-type condition and of being an invaluable resource for further hypothesis-driven research.

\section{Mutant genetic screens in model organisms: a histori- cal perspective}

Multicellular organisms develop from a unicellular zygote by highly regulated processes that result in progressively increased structural complexity. During embryonic development, a hierarchy of gene products participates in cell specification and morphogenetic pathways that cooperatively build the architecture of the adult body. Understanding how genetic information is integrated and used for the elaboration of complex biological patterns is among the main challenges of developmental biology.

Soon after the rediscovery of Mendel's laws in 1900, pioneering genetic studies conducted on the fruit fly (Drosophila melanogaster) in the laboratory of Thomas $\mathrm{H}$. Morgan led to the discovery that genes are physically located on chromosomes and exist in many allelic forms (reviewed by Sturtevant, 1965). Morphological variation was soon recognized as being caused by spontaneous mutations at very low rates, which could be increased experimentally (Müller, 1927). It is generally agreed that such mutations are a powerful tool for unraveling the normal function of individual genes during development.

Forward genetic approaches begin with the induction and isolation of mutants affected in a given process and then infer the biological role of mutated genes based on their associated phenotypes. In this way, high-throughput isolation of morphological mutants and the cloning of the corresponding genes have increased our knowledge of the events that take place during development in organisms such as fungi, nematodes, insects, vertebrates, and plants. One limitation of mutant screens is that mutations that produce subtle phenotypes are likely to remain undetected. A combination of reverse genetics, clonal analysis, and cell biology techniques provides the toolbox to overcome this problem and will help identify all genetically detectable functions at work during the development of complex organisms.

The fruit fly offers many advantages as an experimental organism for developmental genetic studies, including its small size, short life cycle, high fertility, and relatively small genome (Rubin and Lewis, 2000). Because even subtle wing deformations can easily be detected, mutations altering wing shape or wing venation were among the first to be studied at a large scale (Waddington, 1940). Four decades later, embryonic development of the fruit fly was examined with a saturation mutagenesis screen (Nüsslein-Volhard and Wieschaus, 1980; Nüsslein-Volhard et al., 1984). From approximately 27,000 lines, 580 mutants with defects in the larval segmentation pattern were identified, affecting 139 different genes (Table 1). Many of these genes are now known to encode transcription factors necessary for cell fate specification along the anteroposterior and dorsoventral embryonic axes (reviewed by Nüsslein-Volhard, 1991). These studies highlighted for the first time how a complex morphogenetic pattern emerges from a few local signals or morphogens that regulate hierarchies of downstream transcription factors, which interact to delimit cellular territories in the adult body (Nüsslein-Volhard, 1995). More recently, the use of sophisticated imaging techniques to visualize subtle patterning defects has allowed detailed screens aimed at the genetic dissection of other complex processes, such as neuronal morphogenesis (Gao et al., 1999; Table 1).

Despite its late adoption as a model organism (Brenner, 1974), genetic screens performed with the nematode Caenorhabditis elegans were also important for the characterization of cell differentiation pathways, such as the differentiation of the vulva from undifferentiated epidermal cells (Ferguson and Horvitz, 1985; Ferguson et al., 1987). In these screens, 95 mutations defining 22 genes were identified and later found to participate in two highly conserved signaling pathways required for cell fate specification (reviewed by Wang and Sternberg, 2001). The possibility of silencing target genes by RNA interference (RNAi) has greatly accelerated the search for loss-of-function phenotypes in C. elegans (Kamath etal., 2003). For instance, a genomewide RNAi screen allowed researchers to identify 661 genes required for the first two rounds of cell division in the nematode embryo (Sönnichsen et al., 2005; Table 1).

Many genes involved in axial specification in $D$. melanogaster 
TABLE 1

\section{SOME GENETIC SCREENS FOR DEVELOPMENTAL MUTANTS IN MODEL ORGANISMS}

\begin{tabular}{|c|c|c|c|c|}
\hline Model organism & Screened for & Mutants recovered & Genetic loci involved & Degree of saturation reached ${ }^{\mathrm{a}}$ \\
\hline \multirow[t]{2}{*}{ Drosophila melanogaster } & Embryo lethality and larval cuticle defects ${ }^{1,2}$ & 580 & 139 & 98.5 \\
\hline & Defects in dendritic outgrowth, branching, and routing ${ }^{3}$ & $25^{\mathrm{b}}$ & 12 & n.a. \\
\hline \multirow[t]{2}{*}{ Caenorhabditis elegans } & Altered cell lineages of the vulva ${ }^{4}$ & 95 & 22 & 98.7 \\
\hline & Defects in the first two rounds of cell division in the embryo ${ }^{5}$ & 661 & 661 & n.a. \\
\hline \multirow[t]{2}{*}{ Danio rerio } & Abnormal embryonic and early larval phenotypes ${ }^{6}$ & 331 & 220 & 77.8 \\
\hline & Visible phenotype in embryos or early larvae ${ }^{7}$ & 894 & 372 & 91.0 \\
\hline \multirow[t]{4}{*}{ Arabidopsis thaliana } & Defects in embryonic development ${ }^{8}$ & 90 & n.a. & n.a. \\
\hline & Mutations that disrupt the spatial organization of the embryo ${ }^{9}$ & 77 & 9 & 100.0 \\
\hline & Abnormal trichome development ${ }^{10}$ & 71 & 22 & 96.0 \\
\hline & Viable and fertile mutants with abnormal leaves ${ }^{11}$ & 120 & 94 & 72.2 \\
\hline
\end{tabular}

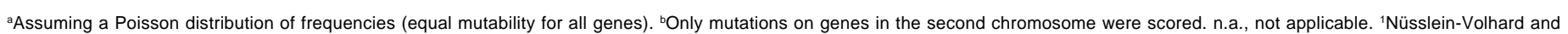

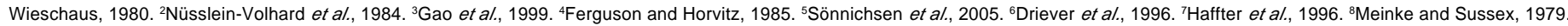
${ }^{9}$ Mayer et al., 1991. ${ }^{10}$ Hülskamp et al., 1994. ${ }^{11}$ Berná et al., 1999.

and $C$. elegans have homologs in vertebrates. The zebrafish (Danio rerio) is the only vertebrate systematically used in forward genetic screens (reviewed by Patton and Zon, 2001). Its translucent embryo is ideal for the identification of mutants deficient in genes required for patterning and differentiation from fertilization to late embryogenesis. In two large-scale screens for visible embryonic phenotypes, more than 1,200 mutants were isolated, which defined at least 550 genes (Driever et al., 1996; Haffter et al., 1996; Table 1). Although these screens failed to saturate the genome with embryonic mutations, they allowed the discovery of mutants with defective blood and heart formation, musculature, and pigmentation. Functional redundancy due to duplicated genes is probably the most severe limitation for determining gene function through mutational approaches in zebrafish (Haffter et al., 1996). New morpholino-based gene silencing protocols have allowed researchers to overcome this problem and systematically knock down selected target genes (Sumanas and Larson, 2002).

Since multicellularity evolved independently in plants and animals, they are expected to use different developmental mechanisms. Like in animals, the basic body plan of plants is laid down during embryogenesis, but, unlike in animals, plant morphogenesis is mostly postembryonic. Mutational approaches became routine in the model plant Arabidopsis thaliana in the early 1990s, after initial screens for embryo-lethal mutants (Meinke and Sussex, 1979). The primary reason for studying seedling lethal mutants with altered spatial embryo organization, initiated by Mayer et al. (1991; Table 1), was to learn about the logic of pattern formation by determining how the embryo responds to the removal of a single, genetically defined component. Although many genes that regulate these early patterning events have been identified, some of them involved in cytokinesis and either auxin signaling or auxin transport, the underlying mechanisms remain poorly understood (reviewed by Jenik et al., 2007).

Genetic analysis has furthered our understanding of the mechanisms responsible for the differentiation of specialized cell types within plant tissues. The ontogeny of trichomes, large polarized cells that are regularly spaced on the leaf surface, has been studied genetically in Arabidopsis thaliana (Hülskamp et al., 1994). In total, 71 mutations that affect trichome morphogenesis and spatial patterning were classified based on the phenotypes produced. Complementation tests indicated that these mutations affect 22 loci (Hülskamp et al., 1994; Table 1). Although additional loci involved in trichome development have been discovered since this early work, an analysis of the cellular phenotypes in single and double mutants has allowed researchers to study specific events in trichome development (reviewed by Schellmann and Hülskamp, 2005) and to propose an elegant model for the differentiation of a specialized cell type from a uniform cell layer. The spatial pattern of presumptive trichome cells is first laid down in the developing leaf, and the committed trichome cells then undergo morphogenesis and differentiation through a defined network of genetic interactions.

Homeotic mutants (i.e., mutants with normal organs in positions typically occupied by another organ type) have facilitated the
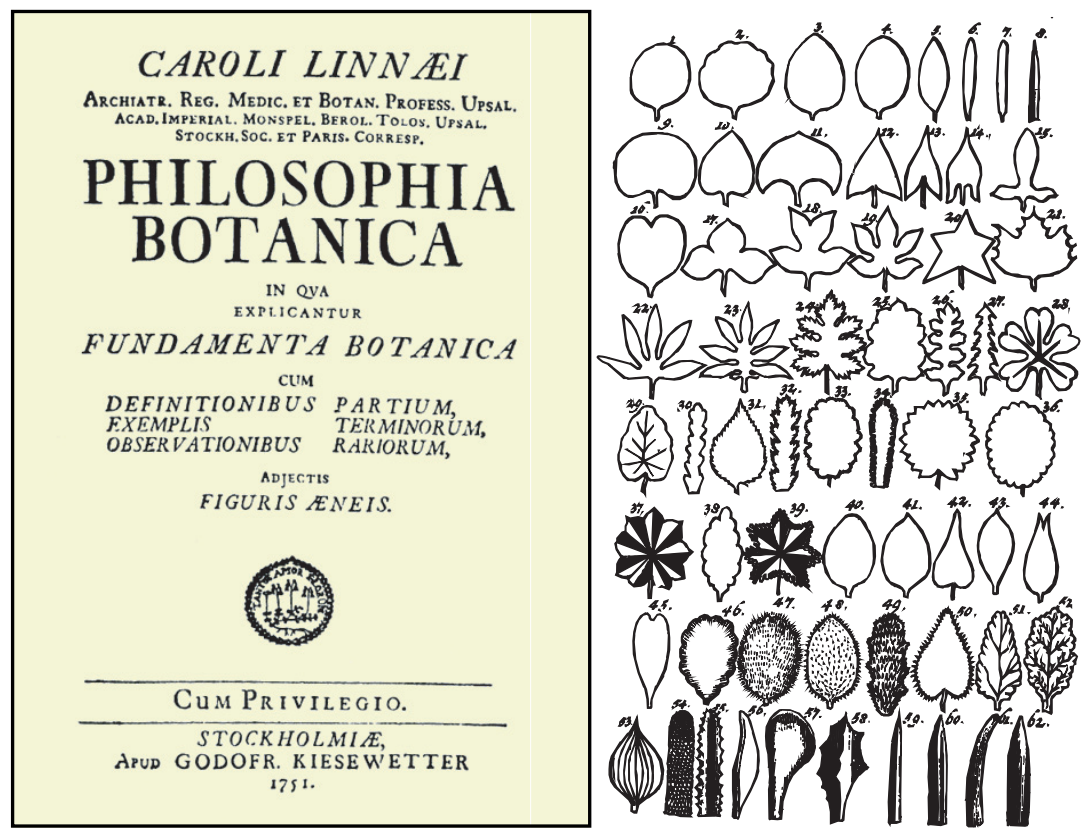

Fig.1. Leaf diversity as seen by Carolus Linnaeus in a page of his Philosophia Botanica (1751). 
identification of organ identity genes responsible for the whorled structure of Arabidopsis thaliana and Antirrhinum majus flowers (reviewed by Meyerowitz et al., 1991). Studies of single and double homeotic mutants in these species led to the ABC model, which states that the identity of each whorl in a wild-type flower is specified by a unique combination of organ identity genes, all of which encode plant transcription factors (reviewed by Coen and Meyerowitz, 1991; Weigel and Meyerovitz, 1994; Ng and Yanofsky, 2000; Coen, 2001).

\section{A search for leaf mutants in Arabidopsis thaliana}

The leaf, one of the most conspicuous organs of higher plants, is the main site of primary productivity and a basic anatomical unit. Plant leaves have determinate growth and develop from a small population of founder cells at the flanks of the shoot apical meristem (Byrne, 2005; Tsukaya, 2005; 2006). In addition to their main role in light harvesting, leaves are also important for nutrient storage, defense, and stress responses. Leaves were considered crucial for taxonomic purposes by Linnaeus (1751) (Fig. 1) and seen as the basic units of plant body architecture by Goethe (1816). It is therefore surprising that in 1993, when the laboratory of José Luis Micol was established, a Medline search using the keywords "Arabidopsis AND leaf AND mutant AND development" yielded only 12 articles. Obviously, plant vegetative development was not receiving much attention from the scientific community at that time. We considered answering questions on how many genes control leaf development and how these genes interact essential to understanding how postembryonic lateral organs are built in plants.

To dissect leaf organogenesis, we followed a forward genetic approach using Arabidopsis thaliana as a model organism. We aimed to identify as many viable and fertile mutants with abnormal leaves as possible, in an attempt to isolate mutant alleles of most genes involved in leaf development. The Lansdberg erecta(Ler; Fig. 3A) accession was selected as the genetic background for our mutagenesis because it is easily grown at high density in the laboratory, has an upright inflorescence that facilitates crossing and seed harvesting, and because the polymorphism between the Ler and Columbia-0 (Col-0) genomes makes genetic mapping and map-based cloning straightforward. The alkylating agent ethyl-methane sulfonate (EMS), by far the most efficient and commonly used mutagen, was chosen because it induces G-toA transitions and has no known bias for particular genomic regions (Greene et al., 2003). Based on codon usage in the Arabidopsis thaliana genome, the frequencies of EMS-induced stop codons and missense mutations are thought to be around 5 and $65 \%$, respectively (McCallum et al., 2000).

In a first screen for leaf mutants (Fig. 2; Berná et al., 1999), we analyzed $46,159 \mathrm{M}_{2}$ seeds derived from $5,770 \mathrm{M}_{1}$ parental lines mutagenized with EMS at the seed stage by a commercial supplier (Lehle seeds; http://www.arabidopsis.com/). In the $\mathrm{M}_{2}$ generation, we found $23.5 \%$ non-germinating seeds and $1.9 \%$ albino plants, as expected for an efficient mutagenesis. After visual inspection of individual $M_{2}$ plants, we selected 1,926 putative mutants ( $4.2 \%$ of the $\mathrm{M}_{2}$ population) with leaves clearly different from those of Ler or that were abnormally arranged in the basal rosette. These mutants were initially assigned to three broad categories, corresponding to alterations in: (1) shape or size of the lamina, (2) margin configuration, or (3) structure of the basal rosette. Many putative $M_{2}$ mutants (853) yielded viable $M_{3}$ progeny but only 333 transmitted their mutant phenotype to the next generation in a Mendelian manner, with complete penetrance and only subtle variation in expressivity. Eighty-one mutants with altered rosette structure were discarded because they were not necessarily affected in the aspects of leaf development that were of interest to us. The inheritance patterns of the remaining 252 mutant lines were determined in backcrosses to Ler. The segregation ratios of the leaf mutant phenotypes were studied in their corresponding $\mathrm{F}_{2}$ families, and the phenotypes of $F_{3}$ inbred descendants from the $F_{2}$ mutant plants were recorded. For subsequent genetic analyses, we selected 153 mutants whose phenotype remained unchanged in the $M_{2}, M_{3}$, and $F_{3}$ generations and was inherited as a monogenic trait.

A complementation test (Lewis, 1939) makes the assessment of allelism possible by crossing any two recessive mutants and analyzing the phenotype of their $\mathrm{F}_{1}$ progeny. Despite the simplicity of this test, the number of crosses required to assign a large collection of mutants to a discrete number of complementation groups becomes enormous and time-consuming even for a moderate number of mutants. For instance, testing the allelism of 153 mutants requires $153 ! /(2 ! \times(153-2) !)=11,628$ crosses. To reduce this number, we defined 19 phenotypic classes (Fig. 3) by grouping mutants with similar characteristics and limited the crosses to mutants within the same class. This seemed reasonable because mutant alleles of the same gene are likely to yield similar phenotypes. The phenotypic classes and the corresponding genes were given Latin names descriptive of their most conspicuous leaf characteristics, inspired by Stearn's Botanical Latin(1995). One exception was the Asymmetric leaves phenotypic class, whose name was already in use for mutants with leaf bilateral asymmetry and a slightly revolute leaf margin (Rédei and Hirono, 1964).

After completing 525 crosses, we assigned our 153 leaf mutants to 94 complementation groups. Since each $M_{1}$ parental was

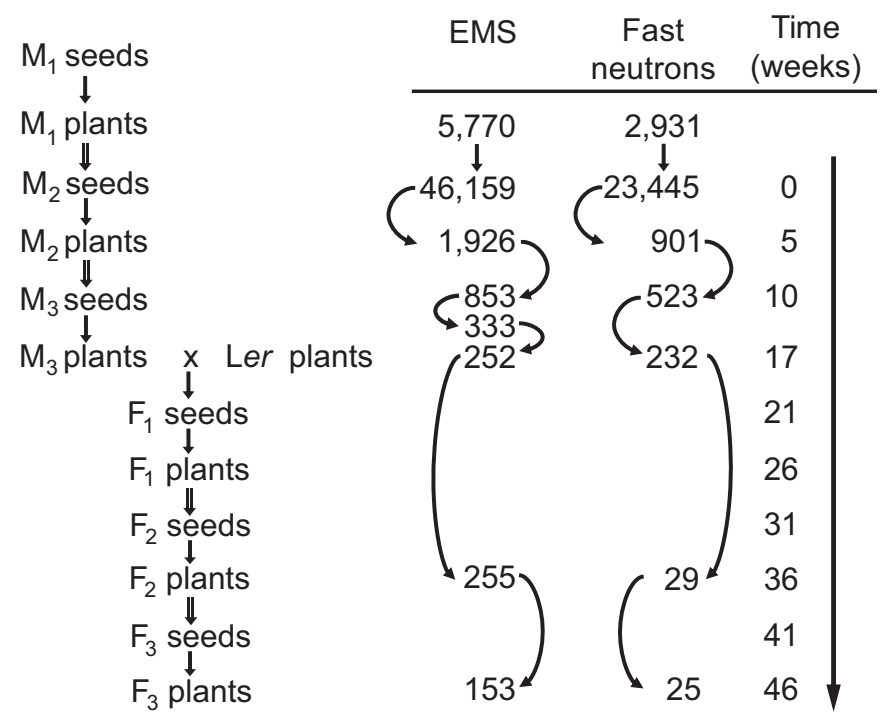

Fig. 2. Flow-chart for the isolation and genetic analysis of leaf mutants. The symbols $\downarrow$ and $\Downarrow$ indicate growth and selfing, respectively. The time scale refers to each mutant. Tasks indicated in italics were outsourced to a company. 

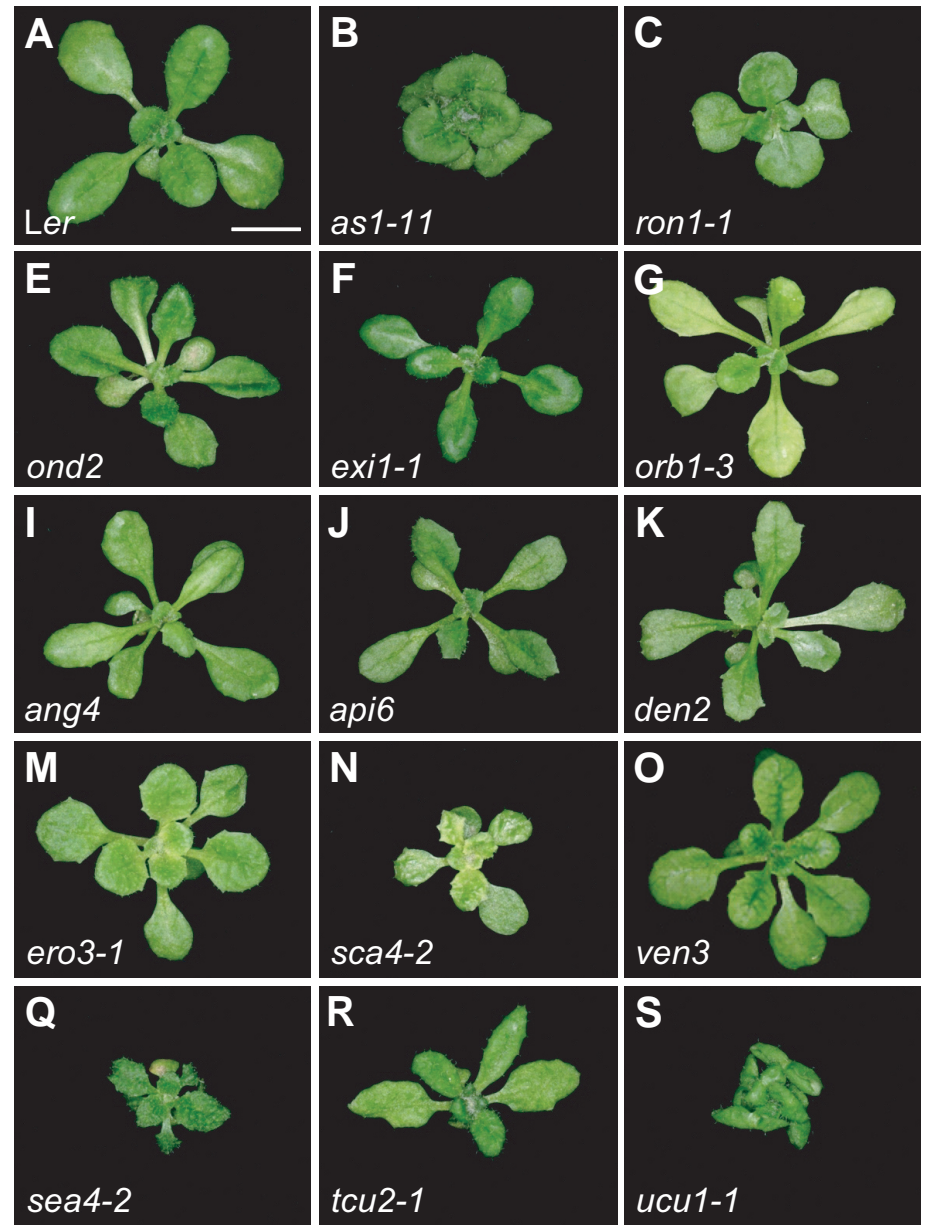

represented by eight $M_{2}$ seeds $(46,159 / 5,770)$, it is possible that allelic mutants isolated from the same parental group represented repeated isolations of the same mutation. Thus, after correcting for this fact, we conservatively estimated the number of different mutations to be 120 . When classified according to their mode of inheritance, 113 of the mutations were recessive, six were semidominant, and only one was completely dominant. According to the number of alleles per gene, the 94 complementation groups were defined by one (76 complementation groups), two (11), three (six), or four (one) mutant alleles.

Assuming equal mutability of all genes, the number of mutant alleles per gene in a mutagenesis experiment is often thought to follow a Poisson probability distribution (Jürgens et al., 1991). To reach saturation, the number of mutants obtained should be high enough to render negligible the probability of a gene not being represented by any mutant allele. With an average of 1.27 (120/ 94) alleles per gene, the fraction of genes that mutate to viable leaf phenotypes but were missed by our screen can be estimated from the zero term of a Poisson distribution to be $e^{-1.27}=27.8 \%$. Although relatively far from saturation, we identified a broad spectrum of leaf morphological alterations that appear in Arabidopsis thaliana after chemical mutagenesis, and they provided us with a precious collection of viable, fertile mutants that has helped us and other groups to dissect specific aspects of leaf development.

Physical mutagenesis with X-rays or fast neutrons normally

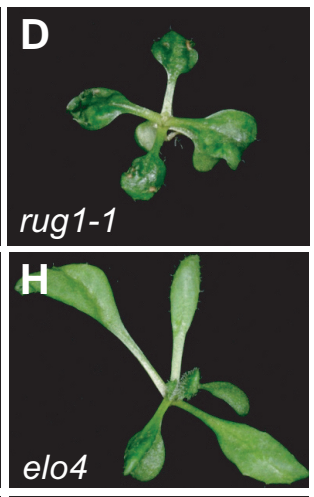

Fig. 3. Pictures showing representative individuals of the phenotypic classes defined for the complementation analysis of mutants with abnormal leaves. The wild-type strain (A) Landsberg erecta (Ler) and the mutants (B) asymmetric leaves1-11 (as1-11), (C) rotunda1-1 (ron1-1), (D) rugosa1-1 (rug1-1), (E) ondulata2 (ond2), (F) exigua1-1 (exi1-1), (G) orbiculata1-3 (orb1-3), (H) elongata4 (elo4), (I) angusta4 (ang4), (J) apiculata6 (api6), (K) denticulata2 (den2), (L) angulata5-1 (anu5-1), (M) erosa3-1 (ero3-1), (N) scabra4-2 (sca4-2), (0) venosa3-3 (ven3-3), (P) dentata1 (dea1), (Q) serrata4-2 (sea4-2), (R) transcurvata2-1 (tcu2-1), (S) ultracurvata1-1 (ucu1-1), and (T) incurvata6 (icu6). Pictures were taken 19 days after sowing. Scale bar is $5 \mathrm{~mm}$.

creates deletions and chromosomal rearrangements (Shirley et al., 1992). In a second screen, we sowed $23,445 \mathrm{M}_{2}$ seeds derived from 2,931 $\mathrm{M}_{1}$ parents irradiated with fast neutrons. We found $1 \%$ albino plants in the $\mathrm{M}_{2}$ population and 901 putative leaf mutants, 523 of which produced $\mathrm{M}_{3}$ seeds (Robles, 1999). In 232 of these mutants, the phenotype was transmitted to the $M_{3}$ generation with complete penetrance and only subtle variation in expressivity. We selected 25 mutant lines with stable phenotypes and grouped them into five phenotypic classes. Complementation tests allowed us to conclude that they represented eight damaged genes (Robles and Micol, unpublished results).

The Arabidopsis Information Service (AIS) Form Mutants collection, which includes mutants isolated by G. Röbbelen and A. R. Kranz, was the largest morphological mutant collection available at that time. We selected 115 AIS form mutants for genetic analysis (Serrano-Cartagena et al., 1999). The leaf mutant phenotypes were inherited as recessive monogenic traits and were classified into 11 previously defined phenotypic classes (Berná et al., 1999), plus three new classes. These AIS mutants fell into 37 complementation groups. The most abundant class, Incurvata (Icu), comprised 22 mutants with involute (curled upward) vegetative leaves, falling into ten different complementation groups. The study of double mutants involving alleles of five $I C U$ genes allowed us to classify them into three groups based on the genetic interactions detected among them (Serrano-Cartagena et al., 2000).

In addition to experimentally induced mutants, we also used natural allelic variation to study the genetic basis of leaf morphogenesis. We screened 188 natural accessions for variations in leaf architecture. These lines were grown under strictly controlled environmental conditions and assigned to 14 phenotypic categories based on petiole length, marginal serration, and overall lamina shape (Pérez-Pérez et al., 2002a). Accessions showing extreme and opposite variations were crossed and their progeny studied. Continuous variation was present in the $F_{2}$ progeny, as expected for polygenic traits. Interestingly, leaf shape and size were among the characters initially studied by Mendel but were 
finally discarded by him due to difficulties in assigning the observed variation to discrete classes (Lewis, 2001). Our results suggested that diverse leaf morphology in Arabidopsis thaliana results from natural allelic variation at quantitative trait loci (QTL). These observations prompted us to characterize leaf morphology in two recombinant inbred line (RIL) populations, derived from Ler-0 $x$ Col-4 and Ler $x$ Cvi crosses, in an attempt to detect, map, and estimate the effects of the QTL responsible for the differences between natural accessions (Pérez-Pérez et al., 2002a; Juenger et al., 2005). We detected 16 and 13 QTL affecting highly correlated leaf morphological traits in juvenile and adult leaves, respectively, using the Ler x Col-4 RIL population, and three additional QTL for juvenile leaf traits using the Lerx Cvi RIL population. Finding QTL confirmed the multifactorial nature of the observed variation in leaf architecture among Arabidopsis thaliananatural accessions.

Leaf venation follows a complex

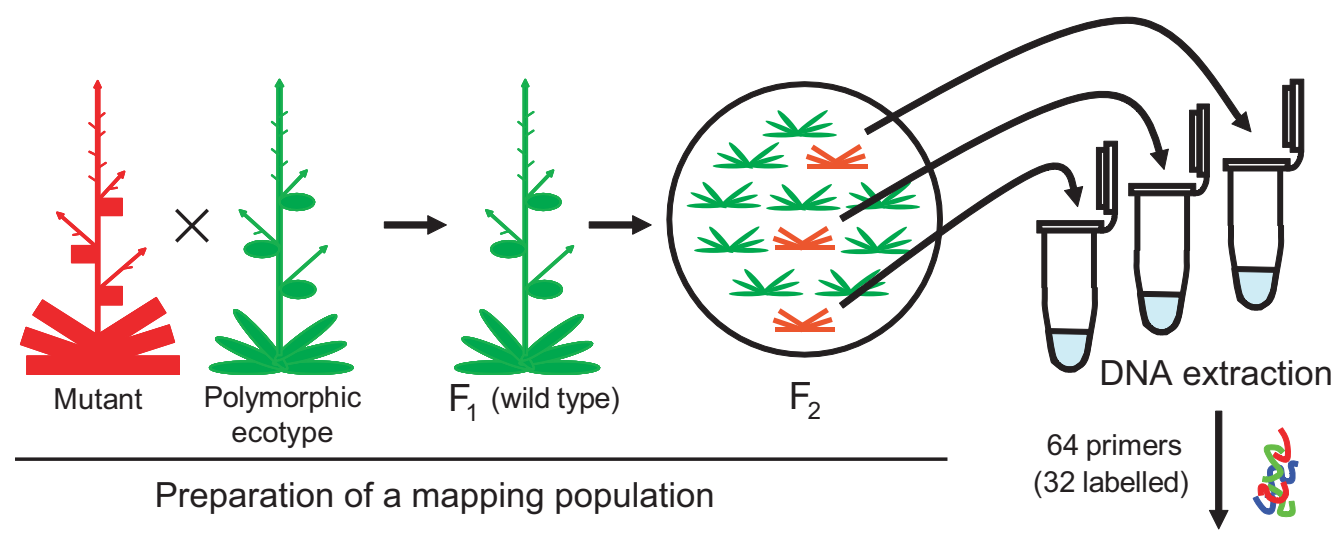

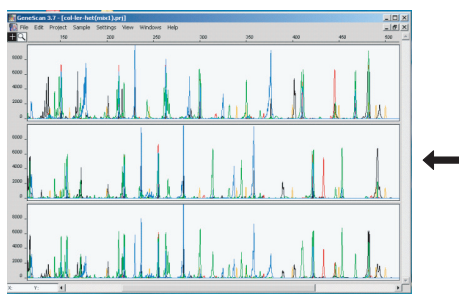

Fragment analysis

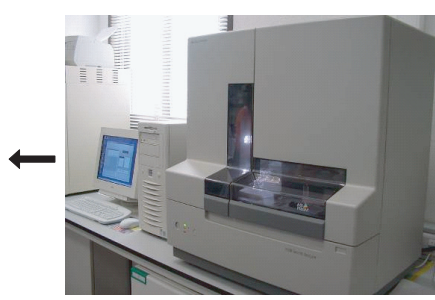

Semiautomated capilar electrophoresis

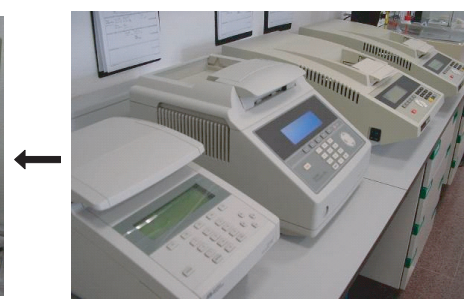

Multiplex PCR amplification

Fig. 4. Schematic representation of our high-throughput gene mapping method. To assess the linkage of a given phenotype to polymorphic molecular markers, the mutant line was first outcrossed to the Columbia0 accession and the $F_{2}$ plants displaying the recessive phenotype were harvested for their DNA extraction. From each individual $F_{2}$ plant, DNA was amplified in a single-tube multiplex PCR as described in Ponce et al. (1999, 2006). The amplification products were electrophoresed in an ABI PRISM 3100 and sized with fragment analysis software.

net-like pattern in Arabidopsis thaliana. We also screened for natural variants in the venation pattern of the first vegetative leaves in 266 Arabidopsis thaliana accessions, finding two, Ba-1 and Ei-5, with abnormal vascular patterns. Ei-5 has an extremely simple pattern that we named Hemivenata and is inherited as a monogenic recessive trait (Candela et al., 1999). Finally, to test if vascular patterning is regulated independently of whole leaf morphogenesis, we screened for mutants with abnormal vein patterns and normal leaf shape and size. More than 6,000 EMSmutagenized $M_{2}$ seeds and 17,313 $T_{4}$ plants derived from 1,800 independent T-DNA transformants were screened but only one mutant was found, extrahydathodes (ehy), characterized by the presence of an increased number of hydathodes per leaf (Candela et al., 1999). These results suggest a direct relationship between leaf venation patterning and leaf morphogenesis in Arabidopsis thaliana.

\section{High-throughput gene mapping as an alternative to massive complementation analysis}

From our screens for leaf mutants using either EMS or fast neutrons as mutagens, and those mutants obtained by other authors, we ended up with 94,8 , and 37 genes, respectively (see above). As an alternative to massive crossing for testing the allelism of mutations affecting leaf development, we developed a high-throughput mapping procedure based on simultaneous PCR coamplification, fluorescent semiautomated detection, and sizing of several microsatellite markers (Ponce et al., 1999), which

allowed us to assign map positions to 97 of these genes (Robles and Micol, 2001). Allelism tests were subsequently performed only for closely linked mutations.

A major step in the genetic characterization of a mutant is the molecular identification of the corresponding gene affected by the mutation. Mutations tagged by insertional mutagenesis often facilitate the recovery of the genomic sequences flanking the insertional element. A drawback of this approach is that insertional mutagenesis usually yields null alleles that might be lethal if homozygous. In contrast, chemical mutagenesis is more efficient and usually produces viable hypomorphic and antimorphic alleles (Noveroske et al., 2000).

Map-based cloning is a classic approach for the molecular identification of a gene when a molecular tag is not available. It involves genotyping the individuals of an $\mathrm{F}_{2}$ mapping population to identify recombination events that occurred in $F_{1}$ hybrids derived from an outcross involving the mutant of interest (Fig. 4). With the completion of the genome sequence and the availability of enough molecular markers to cover the entire genome, mapbased cloning emerged as a powerful approach to identifying genes altered by mutation in many experimental organisms, including plant species other than Arabidopsis thaliana (Bortiri et al., 2006). The number of polymorphic markers and $F_{2}$ individuals needed to detect unambiguous linkage between the mutation under study and a linked genetic marker is proportional to genome size. In Arabidopsis thaliana, with a genome of $500 \mathrm{cM}(125 \mathrm{Mb})$ distributed on five chromosomes, a minimum of 17 markers regularly spaced every $30 \mathrm{cM}$ and a mapping population of 15-20 
$\mathrm{F}_{2}$ plants are required to significantly detect linkage between a mutation under sudy and at least one marker (Ponce et al., 1999). Several high-throughput but low-resolution mapping approaches have been developed in Arabidopsis thaliana: PCR-based mapping with simple sequence length polymorphism (SSLP) markers, either alone (Ponce etal., 1999) or combined with small insertions and deletions (Jander et al., 2002; Ponce et al., 2006), with amplified fragment length polymorphism (AFLP) markers (Peters et al., 2004), or with high-density oligonucleotide array hybridizations (Spiegelman et al., 2000; Gong et al., 2004). The last approach has been useful for mapping moderately large deletions such as those induced by physical mutagens.

Based on our experience, successful positional cloning of Arabidopsis thaliana genes starts with low resolution mapping of a mutation using about $50 \mathrm{~F}_{2}$ mutant homozygotes (Ponce et al., 1999; Robles and Micol, 2001). Subsequently, if no obvious candidate gene is found in the genomic region, the mutation is fine mapped using 400-1000 additional $F_{2}$ individuals. Once the $F_{2}$ mapping population is ready, less than 2 weeks are required for low-resolution mapping and less than 2 months for delimiting a 100-200-kb candidate interval (Ponce et al., 2006).

\section{Genes cloned, molecular nature of their products, and processes in which they are involved}

The map positions obtained with the high-throughput method outlined above (Ponce et al., 1999; 2006) have led to the positional cloning of genes identified in our screens (Berná et al., 1999; Serrano-Cartagena et al., 1999; Robles and Micol, unpublished). This is the case for 25 of the 97 mutations we initially mapped, including 86 induced by EMS, nine taken from the AIS collection, one induced by fast neutrons, and one of spontaneous origin (Robles and Micol, 2001). The cloning and functional characterization six of these genes [ICU6, ICU8, ICU9, ICU15, RON1, and RUGOSA2 (RUG2)] is described in manuscripts currently in preparation. We recently cloned another six genes [TRANSCURVATA1 (TCU1), ONDULATA3 (OND3), RUG1, VENOSA1 (VEN1), VEN4, and VEN5], which are under study in our laboratory.

We published, in some cases in collaboration with other groups, the cloning and functional characterization of 13 genes that affect leaf development (Table 2). The first two genes that we cloned, UCU1 and UCU2, encode proteins involved in the signal transduction of brassinosteroids (BR), steroid hormones that control growth processes such as cell expansion, vascular differentiation, and reproductive development. The ucu1 and ucu2 mutants resemble BR-biosynthesis or BR-perception mutants (Fig. 3S): dwarf plants with roots, hypocotyls, stems, and fruits shorter than in the wild type (Pérez-Pérez et al., 2002b; 2004). UCU1 [also called BRASSINOSTEROID INSENSITIVE2 (BIN2); $\mathrm{Li}$ and Nam, 2002] is a member of the SHAGGY/GSK3 family of intracellular protein kinases, which negatively regulate several signal transduction pathways in metazoans, such as those triggered by insulin or the Wingless/Wnt signal (Cohen and Frame, 2001). In Arabidopsis thaliana, UCU1 may act as a negative modulator of the BR transduction pathway and likely in the crosstalk of the BR and auxin signaling pathways (Pérez-Pérez et al., 2002b). UCU2encodes a peptydil-prolyl cis/trans-isomerase of the FK506-binding protein family involved in protein activation. In addition to BR signaling, UCU2 might also be required for the transport of auxin and, like UCU1, UCU2 plays an important role in the overlap between BR and auxin signaling pathways during leaf expansion (Pérez-Pérez et al., 2004).

In collaboration with Mieke van Lijsebettens' group, RON2 was identified as the same gene as $\angle E U N I G$ ( $\angle U G$, Conner and Liu, 2000), which encodes a WD40 repeat protein similar to transcriptional co-repressors in yeast, Drosophila, and humans (Cnops et al., 2004). RON2 seems to act at the late stages of leaf development and may control leaf growth through restriction of cell expansion. Perturbation of RON2activity causes an increase in leaf cell size, as observed in the ron2 mutants, which display wider laminae and longer petioles than the wild type (Cnops etal., 2004). ELO1, ELO2, and ELO3 are orthologs of the yeast genes $E L P 4, E L P 1$, and $E L P 3$, respectively, whose products form part of the Elongator complex (Nelissen et al., 2005), a histone acety transferase that co-purifies with RNA polymerase II and facilitates the passage of the polymerase along the template during transcription elongation (Otero et al., 1999; Hawkes et al., 2002). The ELO4 gene is the same gene as DEFORMED ROOTS AND $\angle E A V E S 1$ ( $D R L$ ), an ortholog of the yeast TOT4/KTI12 gene

TABLE 2

\section{GENES IDENTIFIED BY POSITIONAL CLONING USING MUTANTS ISOLATED IN OUR LABORATORY}

\begin{tabular}{|c|c|c|c|c|}
\hline Mutants & Genes affected & Alternative gene names & Function of the gene cloned & Developmental process \\
\hline ultracurvata1 (ucu1) & $U C U 1^{1}$ & $B I N 2^{2}$ & Signal transduction of brassinosteroids and auxin & Polar cell expansion \\
\hline ultracurvata2 (ucu2) & $U C U 2^{3}$ & $T W D 1^{4}$ & Signal transduction of brassinosteroids and auxin & Polar cell expansion \\
\hline rotunda2 (ron2) & $R O N 2^{5}$ & $L U G^{6}$ & Transcriptional co-repressor & Restriction of leaf cell expansion \\
\hline \multirow[t]{2}{*}{ elongata (elo1-elo4) } & ELO1-ELO3 ${ }^{7}$ & & Elongation of nuclear gene transcription & Leaf lateral expansion \\
\hline & $E L O 4^{8}$ & $D R L 1^{8}$ & & \\
\hline reticulata (re) & $R E^{9}$ & $L C D 1^{10}, V E N 2^{11}$ & Unknown function & $\begin{array}{l}\text { Differential contribution of the epidermal and internal tissues to leaf } \\
\text { organogenesis }\end{array}$ \\
\hline incurvata4 (icu4) & $\operatorname{ICU} 4^{12}$ & $C N A^{13}$ & Transcription factor & Meristem activity \\
\hline scabra3 (sca3) & $S C A 3^{14}$ & & Chloroplast gene transcription & Relationship between plastid biogenesis and leaf organogenesis \\
\hline hemivenata (hve) & $H V E^{15}$ & CAND $1^{16}$, ETA2 $^{17}$ & Ubiquitination & Venation pattern formation \\
\hline angusta4 (ang4) & ANG4 ${ }^{18}$ & HUB1 ${ }^{19}$ & Histone ubiquitination & Cell cycle regulation \\
\hline incurvata2 (icu2) & $I C U 2^{20}$ & & DNA replication & Chromatin-mediated cellular memory \\
\hline
\end{tabular}

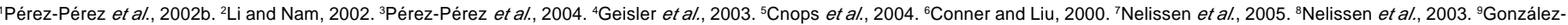

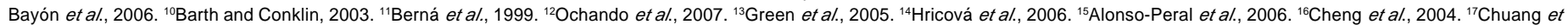
al., 2004. ${ }^{18}$ Fleury et al., 2007. ${ }^{19}$ Liu et al., 2007. ${ }^{20}$ Barrero et al., 2007. 
putatively involved in the regulation of the Elongator complex (Nelissen et al., 2003). Perturbation of the ELOgenes causes a reduction in overall cell division rate that explains the delay in germination and the retarded seedling and primary root growth observed in elo mutants (Fig. $3 \mathrm{H}$ ). The product of HISTONE MONOUBIQUITINATION1 (HUB1; initially named ANGUSTA4 [ANG4]), is a functional homolog of yeast and human histone H2B-monoubiquitinating BRE1 E3 ligases (Fleury et al., 2007; Liu et al., 2007), which are associated with chromatin modifications and transcriptional activation. Mutations in $H U B 1$ affect plant growth and cause reduced plant size, narrow leaves (Fig. 3I), and a reduction in root growth rate, as a consequence of a block in the G2-to-M transition and a prolonged duration of the cell cycle, as also revealed by microarray analyses (Fleury et al., 2007). HUB1 controls gene activation and cell cycle regulation in leaf cells through chromatin modifications.

Together with Antonio Martínez-Laborda's group, we found that the ICU4 gene, also known as CORONA (CNA; Green et al., 2005), encodes the HD-ZIPIII transcription factor ATHB15 (Ochando et al., 2006). The transcripts of ICU4 and other HDZIPIII genes have a microRNA (miRNA) complementary site and are under post-transcriptional regulation. The semidominant icu41 and icu4-2alleles carry identical nucleotide substitutions at the miRNA165/166 complementary site of ICU4. These mutations lead to defective cleavage and accumulation of /CU4transcripts in semidominant icu4 mutants. Phenotypic studies revealed that ICU4plays an adaxializing role in leaves, and is required for shoot meristem function and for the patterning of shoot vascular bundles (Ochando et al., 2006).

The scabra3 (sca3) mutant, with characteristic pale green leaves, shares with re mutants a marked decrease in mesophyll cell number. The SCA3 protein corresponds to the nuclear encoded plastid-targeted RNA polymerase RpoTp, which controls the expression of a subset of plastid genes (Hricová et al., 2006). Strong loss-of-function sca3 alleles affect the number, size and morphology of chloroplasts, and perturb the expression of both plastid and nuclear genes, many encoding chloroplast-targeted proteins (Hricová et al., 2006). Our analyses of sca3 mutants demonstrate the intertwining of plastid biogenesis and leaf organogenesis.

The hemivenata-1 (hve-1) recessive allele was isolated in a search for natural variants of the Arabidopsis thalianaleaf venation pattern (Candela et al., 1999). hve-1 reduces the complexity of the venation pattern in leaves and cotyledons. The HVE1gene encodes the Arabidopsis thaliana ortholog of the mammalian CAND1 protein (Alonso-Peral et al., 2006), which binds to unneddylated CULLIN1 (CUL1), a protein that forms part of the SCF ubiquitin ligase complexes that regulate target protein degradation through the $26 \mathrm{~S}$ proteasome. Similar venation patterns in auxin resistant1 (axr1), a mutant insensitive to auxin, and hve mutants indicate that auxin signaling mediated by ubiquitination is required for venation patterning in Arabidopsis thalianaleaves (Alonso-Peral et al., 2006).

INCURVATA2(ICU2) encodes the putative catalytic subunit of the DNA polymerase $\alpha$ of Arabidopsis thaliana (Barrero et al., 2007). Genetic and molecular interactions between chromatin remodeling factors and components of the DNA replication machinery have been identified in yeast. The weak icu2-1 allele causes early flowering, leaf incurvature, and homeotic transfor- mations in flowers, traits that can be attributed to derepression of flowering time, floral meristem, and floral organ identity genes, respectively. Our genetic analyses indicate that ICU2 interacts with TERMINAL FLOWER2, the ortholog of HETEROCHROMATIN PROTEIN1 of animals and yeasts (Takada and Goto, 2003), and with the Polycomb group (PcG) gene CURL Y LEAF(Goodrich et al., 1997). Our results suggest the existence in plants of a cellular memory mechanism that involves DNA polymerase $\alpha$, as proposed by previous authors for the fission yeast.

Contrary to all genes discussed above, no clear function could be assigned to the RETICULATA $(R E)$ gene (González-Bayón et al., 2006), named $\angle O W E R C E L L D E N S I T Y 1$ ( $\angle C D 1)$ by Barth and Conklin (2003). The $R E$ gene is ubiquitously expressed, and the RE protein has been identified in the chloroplast proteome (Dunkley et al., 2006). The re mutant was initially isolated by Rédei and Hirono (1964), and used as a classic phenotypic marker for mapping for many years. Our histological characterization of re mutants shows a significant reduction in mesophyll cell density but little effects on leaf shape, indicating that $R E$ is normally required for the development of internal leaf tissues (GonzálezBayón et al., 2006). These results were obtained in collaboration with the group of Kevin Pyke and suggest that the epidermis plays a major role in controlling leaf shape in Arabidopsis thaliana, whereas the division and expansion of the internal tissues appear to be secondary in this process, as in tobacco leaves (Avery, 1933). Furthermore, reand wild-type leaves have similar shapes, suggesting that the epidermis plays a major role in controlling leaf shape.

\section{Concluding remarks}

From our EMS screen in the crucifer Arabidopsis thaliana, we estimate that about 130 genes [94×100/(100-27.8)] yield morphological leaf phenotypes and hence are required for normal leaf ontogeny. However, this value underestimates the real number of genes because it is based on an average number of alleles per gene (1.27) that did not consider genes not identified in the screen. Estimates that take them into account are expected to be more accurate. By applying the formulae of Rice (1973), Meneely and Herman (1979), and Engels (1981) to our data, we obtain values of 357,279 , and $233 \pm 39$ genes, respectively. An immediate conclusion from these results is that a significant fraction of the genome must work cooperatively to produce a leaf. These values only refer to those genes that can mutate to viable leaf shape phenotypes, and represent a lower limit that does not take into account mutations with pleiotropic effects that prevent their transmission, such as those that cause sterility or are lethal. For example, genes essential for developmental decisions in the embryo may also act at later stages, but the study of their postembryonic functions will only be possible using special techniques, such as clonal analysis.

Mutations in genes required for the establishment of shoot meristem and leaf identities have been extensively studied in plants. In maize, ectopic expression of class I KNOX genes in dominant Knotted1 and Rough sheath1 mutants causes abnormal cell proliferation and differentiation patterns (Hake et al., 1989; Schneeberger et al., 1995). The rough sheath2 gene of maize (Tsiantis et al., 1999) and its orthologs PHANTASTICA (PHAN; Waites et al., 1998) and ASYMMETRIC LEAVES1(AS1; 
Byrne et al., 2000) from Antirrhinum majus and Arabidopsis thaliana, respectively, encode transcription factors that downregulate class I KNOXgenes in leaves (Hake et al., 2004). Other genes such as SERRATE (SE; Grigg et al., 2005) and AS2 (Iwakawa et al., 2002) also participate in the KNOX regulatory pathway in leaf primordia, helping to establish their identity as lateral organs. Our leaf mutant screens identified new alleles of $A S 1$ (Fig. 3B), $A S 2$, and SE, whose molecular characterization may help to define functional domains in the corresponding proteins.

We deliberately excluded those mutations that cause normal leaf shape and altered phyllotaxy because they might affect genes that regulate aspects of leaf initiation but are not directly involved in leaf morphogenesis. However, other genes known to be important for leaf organogenesis are not represented in our collection of mutants. Indeed, our screens failed to identify alleles of some genes crucial for leaf polarity, such as members of the $Y A B B Y$ and $K A N A D /$ families (reviewed by Byrne, 2005), probably because these families have functionally redundant members.

We failed to identify new alleles of the ANGUSTIFOLIA $(A N)$ and ROTUNDIFOLIA (ROT) genes, whose mutations specifically affect cell expansion along the proximodistal and mediolateral axes of the leaf, respectively (Tsuge et al., 1996). Despite previous authors have reported compensatory cell enlargement in the leaves of mutants affected in cell proliferation (reviewed by Tsukaya, 2003), we have not observed such a compensation in the mutants characterized so far at the cellular level in our laboratory. Further histological characterization of our collection of leaf mutants may identify some that undergo similar compensation.

The leaves of the cincinnata ( $\operatorname{cin}$ ) mutant of Antirrhinum majus are crinkly (instead of flat) due to excessive growth of marginal tissues. CIN encodes a transcription factor of the TCP family (Nath et al., 2003). Analysis of the dominant jaw mutant of Arabidopsis thaliana revealed that expression of TCP genes in leaf margins is regulated by miRNAs, which are also required for leaf flatness (Palatnik et al., 2003). No alleles of TCP genes or of the JAW miRNA gene have been identified among our mutants. However, we found alleles of genes that encode components of the miRNA pathway (Ponce and Micol, unpublished), including HASTY (Park et al., 2005), ARGONAUTE1 (Kidner and Martienssen, 2004), HUA ENHANCER1 (HEN1; Park et al., 2002), and HYPONASTICLEAVES1 (HYL1; Han et al., 2004), as well as a miRNA target, ICU4 (Ochando et al., 2006).

The cloning of 25 genes identified by mutation in our laboratory shows that many unrelated processes converge in leaf morphogenesis. It is remarkable that, when classified according to function, 15 of the cloned genes encode regulators of gene expression. This enrichment suggests that mutations in genes necessary for basic metabolic functions, which are also expected to yield visible leaf phenotypes, are selected against at the haploid gametophytic phase or at early stages of the diploid phase of the life cycle, soon after fertilization. Furthermore, all the mutants that we have studied in detail display pleiotropic phenotypes in other organs, such as the flowers; in agreement with Goethe's classic hypothesis that all plant laminar organs are modified leaves.

As noted by Jürgens (1992), the identification of all genes that participate in a given biological process is necessary to under- stand how the process works. A genetic dissection normally begins with the isolation of mutations perturbing the normal course of development, to identify the genes at work in the process under study. A high-throughput genetic screen for mutants with altered leaf size and shape aiming to understand the mechanisms of leaf-size control was recently published (Horiguchi et al., 2006a; 2006b). A comparative study between these two large collections of mutants should help to identify most of the genes involved in leaf growth and development in Arabidopsis thaliana. The positional cloning of untagged mutations in model organisms such as Arabidopsis thalianahas proved a very fruitful approach even though it occasionally yields genes with very limited novelty or involved in totally unexpected functions. We have shown that the range of leaf phenotypes identified in our laboratory results from perturbation of a variety of unrelated gene functions. Combined with elegant work by other authors, our results have begun to reveal the outstanding complexity of leaf development. The molecular identification of additional genes uncovered by mutation will provide a better picture of how leaves develop and is expected to help explain the immense diversity in leaf shape and leaf size present in nature.

\section{Acknowledgments}

The authors wish thank S. Gerber, J.M. Serrano, V. Garcia, and T. Trujillo for technical assistance during all these years, and $M$. van Lijsebettens, V. Aguilera, A. Mollá-Morales, A. Ferrández-Ayela, R. Sarmiento-Mañús, D. Hernández-Romero, and S. Rubio-Díaz for comments on the manuscript. This work was supported by grants from the Ministerio de Educación y Ciencia of Spain [PB91-0749, APC95-0191, PB95-0685, PB98-1309, BMC2002-02840, BMC2005-01031, BIO200804075 and CSD2007-00057 (TRANSPLANTA)] and the European Commission [HPRN-CT-2002-00267 (DAGOLIGN) and LSHG-CT-2006037704 (AGRON-OMICS)].

\section{References}

ALONSO-PERAL, M.M., CANDELA, H., DEL POZO, C., MARTÍNEZ-LABORDA A., PONCE, M.R. and MICOL, J.L. (2006). The HVEICAND1 gene is required for the early patterning of leaf venation in Arabidopsis. Development 133: 375566.

AVERY, G.S.J. (1933). Structure and germination of tobacco seed and the developmental anatomy of the seedling plant. Am J Bot 20: 309-27.

BARRERO, J.M., GONZÁLEZ-BAYÓN, R., DEL POZO, J.C., PONCE, M.R. and MICOL, J.L. (2007). INCURVATA2 encodes the catalytic subunit of DNA polymerase alpha and interacts with genes involved in chromatin-mediated cellular memory in Arabidopsis thaliana. Plant Cel/ 19: 2822-38.

BARTH, C. and CONKLIN, P.L. (2003). The lower cell density of leaf parenchyma in the Arabidopsis thaliana mutant $/ c d 1-1$ is associated with increased sensitivity to ozone and virulent Pseudomonas syringae. Plant J35: 206-18.

BERNÁ, G., ROBLES, P. and MICOL, J.L. (1999). A mutational analysis of leaf morphogenesis in Arabidopsis thaliana. Genetics 152: 729-42.

BORTIRI, E., JACKSON, D. and HAKE, S. (2006). Advances in maize genomics: the emergence of positional cloning. Curr Opin Plant Bio/9: 164-71.

BRENNER, S. (1974). The genetics of Caenorhabditis elegans. Genetics 77: 71-94. BYRNE, M.E. (2005). Networks in leaf development. Curr Opin Plant Bio/8: 59-66.

BYRNE, M.E., BARLEY, R., CURTIS, M., ARROYO, J.M., DUNHAM, M., HUDSON A. and MARTIENSSEN, R.A. (2000). Asymmetric leaves1 mediates leaf patterning and stem cell function in Arabidopsis. Nature 408: 967-71.

CANDELA, H., MARTíNEZ-LABORDA, A. and MICOL, J.L. (1999). Venation pattern formation in Arabidopsis thalianavegetative leaves. Dev Bio/205: 20516.

CHENG, Y., DAI, X. and ZHAO, Y. (2004). AtCAND1, a HEAT-repeat protein that 
participates in auxin signaling in Arabidopsis. Plant Physio/135: 1020-6.

CHUANG, H.W., ZHANG, W. and GRAY, W.M. (2004). Arabidopsis ETA2, an apparent ortholog of the human cullin-interacting protein CAND1, is required for auxin responses mediated by the SCF(TIR1) ubiquitin ligase. Plant Cel/ 16: 1883-97.

CNOPS, G., JOVER-GIL, S., PETERS, J.L., NEYT, P., DE BLOCK, S., ROBLES, P., PONCE, M.R., GERATS, T., MICOL, J.L. and VAN LIJSEBETTENS, M. (2004). The rotunda2 mutants identify a role for the LEUNIG gene in vegetative leaf morphogenesis. J Exp Bot 55: 1529-39.

COEN, E.S. (2001). Goethe and the ABC model of flower development. C R Acad Sci Paris, Sciences de la vie: 1-8.

COEN, E.S. and MEYEROWITZ, E.M. (1991). The war of the whorls: genetic interactions controlling flower development. Nature 353: 31-7.

COHEN, P. and FRAME, S. (2001). The renaissance of GSK3. Nat Rev Mol Cel/ Biol 2: 769-76.

CONNER, J. and LIU, Z. (2000). LEUNIG, a putative transcriptional corepressor that regulates AGAMOUS expression during flower development. Proc Nat/ Acad Sci USA 97: 12902-07.

DRIEVER, W., SOLNICA-KREZEL, L., SCHIER, A.F., NEUHAUSS, S.C., MALICKI, J., STEMPLE, D.L., STAINIER, D.Y., ZWARTKRUIS, F., ABDELILAH, S., RANGINI, Z., etal. (1996). A genetic screen for mutations affecting embryogenesis in zebrafish. Development 123: 37-46.

DUNKLEY, T.P., HESTER, S., SHADFORTH, I.P., RUNIONS, J., WEIMAR, T., HANTON, S.L., GRIFFIN, J.L., BESSANT, C., BRANDIZZI, F., HAWES, C., WATSON, R.B., DUPREE, P. and LILLEY, K.S. (2006). Mapping the Arabidopsis organelle proteome. Proc Natl Acad Sci USA 103: 6518-23.

ENGELS, W.R. (1981). On estimating the total number of genes of a given kind in the genome and similar problems. J. Math. Biology 11: 45-50.

FERGUSON, E.L. and HORVITZ, H.R. (1985). Identification and characterization of 22 genes that affect the vulval cell lineages of the nematode Caenorhabditis elegans. Genetics 110: 17-72.

FERGUSON, E.L., STERNBERG, P.W. and HORVITZ, H.R. (1987). A genetic pathway for the specification of the vulval cell lineages of Caenorhabditis elegans. Nature 326: 259-67.

FLEURY, D., HIMANEN, K., CNOPS, G., NELISSEN, H., BOCCARDI, T.M., MAERE, S., BEEMSTER, G., NEYT, P., ANAMI, S., ROBLES, P., MICOL, J.L., INZÉ, D. and VAN LIJSEBETTENS, M. (2007). The Arabidopsis thaliana homolog of yeast BRE1 has a function in cell cycle regulation during early leaf and root growth. Plant Cel/19: 417-32.

FRANKLIN, L.R. (2005). Exploratory experiments. Philos Sci72: 888-99.

GAO, F.B., BRENMAN, J.E., JAN, L.Y. and JAN, Y.N. (1999). Genes regulating dendritic outgrowth, branching and routing in Drosophila. Genes Dev 13: 254961.

GEISLER, M., KOLUKISAOGLU, H.U., BOUCHARD, R., BILLION, K., BERGER, J., SAAL, B., FRANGNE, N., KONCZ-KALMAN, Z., KONCZ, C., DUDLER, R. et al. (2003). TWISTED DWARF1, a unique plasma membrane-anchored immunophilin-like protein, interacts with Arabidopsis multidrug resistance-like transporters AtPGP1 and AtPGP19. Mol Biol Cel/ 14: 4238-49.

GOETHE, J.W. (1816). Italian Journey. Translated by W.H. Auden and E. Mayer. Penguin Classics, London, England, 1970.

GONG, J.-M., WANER, D.A., HORIE, T., LI, S.L., HORIE, R., KHUSH, B.A. and SCHROEDER, J.I. (2004). Microarray-based rapid cloning of an ion accumulation deletion mutant in Arabidopsis thaliana. ProcNat/Acad Sci USA 43: 1540409 .

GONZÁLEZ-BAYÓN, R., KINSMAN, E.A., QUESADA, V., VERA, A., ROBLES, P., PONCE, M.R., PYKE, K. and MICOL, J.L. (2006). Mutations in the RETICULATA gene dramatically alter internal architecture but have little effect on overall organ shape in Arabidopsis leaves. J Exp Bot 12: 3019-31.

GOODRICH, J., PUANGSOMLEE, P., MARTIN, M., LONG, D., MEYEROWITZ, E.M. and COUPLAND, G.A. (1997). Polycomb-group gene regulates homeotic gene expression in Arabidopsis. Nature 386: 44-51.

GREEN, K.A., PRIGGE, M.J., KATZMAN, R.B. and CLARK, S.E. (2005). CORONA, a member of the class III homeodomain leucine zipper gene family in Arabidopsis, regulates stem cell specification and organogenesis. Plant Cel/17: 691-04.
GREENE, E.A., CODOMO, C.A., TAYLOR, N.E., HENIKOFF, J.G., TILL, B.J., REYNOLDS, S.H., ENNS, L.C., BURTNER, C., JOHNSON, J.E., ODDEN, A.R., COMAI, L. and HENIKOFF, S. (2003). Spectrum of chemically induced mutations from a large-scale reverse-genetic screen in Arabidopsis. Genetics 164 731-40.

GRIGG, S.P., CANALES, C., HAY, A. and TSIANTIS, M. (2005). SERRATE coordinates shoot meristem function and leaf axial patterning in Arabidopsis. Nature 437: 1022-6.

HAFFTER, P., GRANATO, M., BRAND, M., MULLINS, M.C., HAMMERSCHMIDT, M., KANE, D.A., ODENTHAL, J., VAN EEDEN, F.J., JIANG, Y.J., HEISENBERG, C.P., et al. (1996). The identification of genes with unique and essential functions in the development of the zebrafish, Danio rerio. Development123: 136 .

HAKE, S., SMITH, H.M., HOLTAN, H., MAGNANI, E., MELE, G. and RAMIREZ, J. (2004). The role of knox genes in plant development. Annu Rev Cell Dev Biol. 20: $125-51$.

HAKE, S., VOLLBRECHT, E. and M. FREELING, M. (1989). Cloning Knotted, the dominant morphological mutant of maize using Ds2as a transposon tag. EMBO J8: 15-22.

HAN, M.H., GOUD, S., SONG, L. and FEDOROFF, N. (2004). The Arabidopsis double-stranded RNA-binding protein HYL1 plays a role in microRNA-mediated gene regulation. Proc Natl Acad Sci USA 101: 1093-8.

HAWKES, N.A., OTERO, G., WINKLER, G.S., MARSHALL, N., DAHMUS, M.E., KRAPPMANN, D., SCHEIDEREIT, C., THOMAS, C.L., SCHIAVO, G., ERDJUMENT-BROMAGE, H., TEMPST, P. and SVEJSTRUP, J.Q. (2002). Purification and characterization of the human elongator complex. $\mathrm{J}$ Biol Chem 277: 3047-52.

HORIGUCHI, G., FERJANI, A., FUJIKURA, U., and TSUKAYA, H. (2006a). Coordination of cell proliferation and cell expansion in the control of leaf size in Arabidopsis thaliana. J Plant Res 119: 37-42.

HORIGUCHI, G., FUJIKURA, U., FERJANI, A., ISHIKAWA, N., and TSUKAYA, H. (2006b). Large-scale histological analysis of leaf mutants using two simple leaf observation methods: identification of novel genetic pathways governing the size and shape of leaves. Plant J48: 638-44.

HRICOVÁ, A., QUESADA, V. and MICOL, J.L. (2006). The SCABRA3nuclear gene encodes the plastid RpoTp RNA polymerase, which is required for chloroplast biogenesis and mesophyll cell proliferation in Arabidopsis. Plant Physiol 141: 942-56.

HÜLSKAMP, M., MISÉRA, S. and JÜRGENS, G. (1994). Genetic dissection of trichome cell development in Arabidopsis. Cel/76: 555-66.

IWAKAWA, H., UENO, Y., SEMIARTI, E., ONOUCHI, H., KOJIMA, S., TSUKAYA, H., HASEBE, M., SOMA, T., IKEZAKI, M., MACHIDA, C. and MACHIDA, Y. (2002). The ASYMMETRIC LEAVES2 gene of Arabidopsis thaliana, required for formation of a symmetric flat leaf lamina, encodes a member of a novel family of proteins characterized by cysteine repeats and a leucine zipper. Plant Cell Physio/43: 467-78.

JANDER, G., NORRIS, S.R., ROUNSLEY, S.D., BUSH, D.F., LEVIN, I.M. and LAST, R.L. (2002). Arabidopsis map-based cloning in the post-genome era. Plant Physiol 129: 440-50

JENIK, P.D., GILLMOR, C.S. and LUKOWITZ, W. (2007). Embryonic patterning in Arabidopsis thaliana. Annu Rev Cell Dev Bio/23: 207-36.

JUENGER, T., PÉREZ-PÉREZ, J.M., BERNAL, S. and MICOL, J.L. (2005). QTL mapping of floral and leaf morphology traits in Arabidopsis thaliana: evidence for modular genetic architecture. Evol Dev 7: 259-71.

JÜRGENS, G. (1992). Pattern formation in the flowering plant embryo. Curr Opin Genet Dev 2: 567-570.

JÜRGENS, G., MAYER, U., TORRES-RUIZ, R.A., BERLETH, T., and MISÉRA, S. (1991). Genetic analysis of pattern formation in the Arabidopis embryo. Deve/opment Supplement 1: 27-38.

KAMATH, R.S., FRASER, A.G., DONG, Y., POULIN, G., DURBIN, R., GOTTA, M., KANAPIN, A., LE BOT, N., MORENO, S., SOHRMANN, M., et al. (2003). Systematic functional analysis of the Caenorhabditis elegans genome using RNAi. Nature 421: 231-37.

KELL, D.B. and OLIVER, S.G. (2004). Here is the evidence, now what is the hypothesis? The complementary roles of inductive and hypothesis-driven science in the post-genomic era. Bioessays 26: 99-105. 
KIDNER, C.A. and MARTIENSSEN, R.A. (2004). Spatially restricted microRNA directs leaf polarity through ARGONAUTE1. Nature 428: 81-4.

LEWIS, E.B. (1939). Star-recessive, a spontaneous mutation in Drosophila melanogaster. Proc Minn Acad Sci 7: 23-6.

LEWIS, R. (2001). Mendel's laws. In Encylopedia of Genetics. S. Brenner and J.H Milller eds., Academic Press, London.

LI, J. and NAM, K.H. (2002). Regulation of brassinosteroid signaling by a GSK3/ SHAGGY-like kinase. Science 295: 1299-301.

LINNAEUS, C. (1751). Philosophia botanica. G. Kiesewetter, Stockholm.

LIU, Y., KOORNNEEF, M. and SOPPE, W.J. (2007). The absence of histone H2B monoubiquitination in the Arabidopsis hub1 (rdo4) mutant reveals a role for chromatin remodeling in seed dormancy. Plant Cel/19: 433-44.

LOCKHART, D.J. and WINZELER, E.A. (2000). Genomics, gene expression and DNA arrays. Nature 405: 827-36.

MARGUliES, M., EGHOLM, M., ALTMAN, W.E., ATTIYA, S., BADER, J.S., BEMBEN, L.A., BERKA, J., BRAVERMAN, M.S., CHEN, Y.J., CHEN, Z.T., etal (2005). Genome sequencing in microfabricated high-density picolitre reactors. Nature 437: 376-80.

MAYER, U., TORRES-RUIZ, R.A., BERLETH, T., MISÉRA, S. and JÜRGENS, G. (1991). Mutations affecting body organization in the Arabidopsis embryo. Nature 353: 402-407.

MCCALLUM, C.M., COMAI, L., GREENE, E.A. and HENIKOFF, S. (2000). Targeted screening for induced mutations. Nat Biotechno/18: 455-57.

MEINKE, D.W., and SUSSEX, I.M. (1979). Embryo-lethal mutants of Arabidopsis thaliana. A model system for genetic analysis of plant embryo development. Dev Bio/72: 50-61.

MENEELY, P.M. and HERMAN, R.K. (1979). Lethals, steriles and deficiencies in a region of the X chromosome of Caenorhabditis elegans. Genetics 92: 99-115.

MEYEROWITZ, E.M., BOWMAN, J.L., BROCKMAN, L.L., DREWS, G.N., JACK, T., SIEBURTH, L.E. and WEIGEL, D. (1991). A genetic and molecular model for flower development in Arabidopsis thaliana. Development Supplement 1: 15767.

MÜLLER, H. J. (1927). Artificial transmutation of the gene. Science 66: 84-7.

MURRAY, A.W. (2000). Whither genomics? Genome Biol1: COMMENT003.

NATH, U., CRAWFORD, B.C., CARPENTER, R. and COEN, E. (2003). Genetic control of surface curvature. Science 299: 1404-7.

NELISSEN, H., CLARKE, J.H., DE BLOCK, M., DE BLOCK, S., VANDERHAEGHEN, R., ZIELINSKI, R.E., DYER, T., LUST, S., INZE. D. and VAN LIJSEBETTENS, M. (2003). DRL1, a homolog of the yeast TOT4/KTI12 protein, has a function in meristem activity and organ growth in plants. Plant Ce//15: 639-54.

NELISSEN, H., FLEURY, D., BRUNO, L., ROBLES, P., DE VEYLDER, L., TRAAS, J., MICOL, J.L., VAN MONTAGU, M., INZÉ, D. and VAN LIJSEBETTENS, M. (2005). The elongata mutants identify a functional Elongator complex in plants with a role in cell proliferation during organ growth. Proc Nat/Acad SciUSA102 7754-59.

NG, M. and YANOFSKY, M.F. (2000). Three ways to learn the ABCs. Curr Opin Plant Bio/3: 47-52.

NOVEROSKE, J.K., WEBER, J.S., and JUSTICE, M.J. (2000). The mutagenic action of N-ethyl-N-nitrosourea in the mouse. Mamm Genome 11: 478-83.

NÜSSLEIN-VOLHARD, C. (1991). Determination of the embryonic axes of Drosophila. Development Supplement 1: 1-10.

NÜSSLEIN-VOLHARD, C. (1995). Nobel Lecture. In NobelLectures, Physiology or Medicine 1991-1995, Nils Ringertz ed., World Scientific Publishing Co., Singapore.

NÜSSLEIN-VOLHARD, C. and WIESCHAUS, E. (1980). Mutations affecting segment number and polarity in Drosophila. Nature 287: 785-801.

NÜSSLEIN-VOLHARD, C., WIESCHAUS, E. and KLUDING, H. (1984). Mutations affecting the pattern of the larval cuticle in Drosophila melanogaster. zygotic loci on the second chromosome. Roux's Arch Dev Bio/193: 267-82.

OCHANDO, I., JOVER-GIL., S., RIPOLL, J.J., CANDELA, H., VERA, A., PONCE, M.R., MARTÍNEZ-LABORDA, A. and MICOL, J.L. (2006). Mutations in the microRNA complementarity site of the INCURVATA4 gene perturb meristem function and adaxialize lateral organs in Arabidopsis. Plant Physio/141: 607-19.

OTERO, G., FELLOWS, J., LI, Y., DE BIZEMONT, T., DIRAC, A.M., GUSTAFSSON,
C.M., ERDJUMENT-BROMAGE, H., TEMPST, P. and SVEJSTRUP, J.Q. (1999). Elongator, a multisubunit component of a novel RNA polymerase II holoenzyme for transcriptional elongation. Mol Cel/3: 109-18.

PALATNIK, J.F., ALLEN, E., WU, X., SCHOMMER, C., SCHWAB, R., CARRINGTON, J.C. and WEIGEL, D. (2003). Control of leaf morphogenesis by microRNAs. Nature 425: 257-63.

PARK, M.Y., WU, G., GONZALEZ-SULSER, A., VAUCHERET, H. and POETHIG, R.S. (2005). Nuclear processing and export of microRNAs in Arabidopsis. Proc Nat/ Acad Sci USA. 102: 3691-6.

PARK, W., LI, J., SONG, R., MESSING, J. and CHEN, X. (2002). CARPEL FACTORY, a Dicer homolog, and HEN1, a novel protein, act in microRNA metabolism in Arabidopsis thaliana. Curr Biol12: 1484-95.

PATTON, E.E., and ZON, L.I. (2001). The art and design of genetic screens: zebrafish. Nat Rev Genet2: 956-66.

PÉREZ-PÉREZ, J.M., PONCE, M.R. and MICOL, J.L. (2002b). The UCU1 Arabidopsis gene encodes a SHAGGY/GSK3-like kinase required for cell expansion along the proximodistal axis. Dev Biol242: 161-73.

PÉREZ-PÉREZ, J.M., PONCE, M.R. and MICOL, J.L. (2004). The ULTRACURVATA2 gene of Arabidopsis thaliana encodes an FK506-binding protein involved in auxin and brassinosteroid signaling. Plant Physio/134: 10117.

PÉREZ-PÉREZ, J.M., SERRANO-CARTAGENA, J. and MICOL, J.L. (2002a). Genetic analysis of natural variations in the architecture of vegetative leaves in Arabidopsis thaliana. Genetics 162: 893-915.

PETERS, J.L., CNOPS, G., NEYT, P., ZETHOF, J., CORNELIS, K., VAN LIJSEBETTENS, M. and GERATS, T. (2004). An AFLP-based genome-wide mapping strategy. Theor App/ Genet 108: 321-27.

PONCE, M.R., ROBLES, P. and MICOL, J.L. (1999). High-throughput genetic mapping in Arabidopsis thaliana. Mol Gen Genet 261: 408-15.

PONCE, M.R., ROBLES, P., LOZANO, F.M., BROTONS, M.A. and MICOL, J.L. (2006). Low-resolution mapping of untagged mutations. Methods Mol Bio/323: 105-13.

RÉDEI, G. P. and HIRONO, Y. (1964). Linkage studies. Arabidopsis Inf Serv1: 9 10.

RICE, T.B. (1973). Isolation and characterization of maternal effect mutants: an approach to the study of early determination in Drosophila melanogaster. Ph.D. thesis, Yale University.

ROBLES, P. (1999). Análisis genético de mutantes de Arabidopsis thaliana con alteraciones en la morfología de la hoja. Ph.D. thesis, Universidad Miguel Hernández de Elche.

ROBLES, P. and MICOL, J.L. (2001). Genome-wide linkage analysis of Arabidopsis genes required for leaf development. Mol Genet Genomics 266: 12-19.

ROGERS, Y.H. and VENTER, J.C. (2005). Genomics - Massively parallel sequencing. Nature 437: 326-27

RUBIN, G.M. and LEWIS, E.B. (2000). A brief history of Drosophila's contributions to genome research. Science 287: 2216-18.

SCHELLMANN, S. and HULSKAMP, M. (2005). Epidermal differentiation: trichomes in Arabidopsis as a model system. Int J Dev Bio/49: 579-84.

SCHNEEBERGER, R.G., BECRAFT, P.W., HAKE, S. and FREELING, M. (1995) Ectopic expression of the knox homeobox gene rough sheath1 alters cell fate in the maize leaf. Genes Dev 9: 2292-304.

SERRANO-CARTAGENA, J., CANDELA, H., ROBLES, P., PONCE, M.R., PÉREZPÉREZ, J.M., PIQUERAS, P. and MICOL, J.L. (2000). Genetic analysis of incurvata mutants reveals three independent genetic operations at work in Arabidopsis leaf morphogenesis. Genetics 156: 1363-77.

SERRANO-CARTAGENA, J., ROBLES, P., PONCE, M.R. and MICOL, J.L. (1999). Genetic analysis of leaf form mutants from the Arabidopsis Information Service collection. Mol Gen Genet 261: 725-39.

SHIRLEY, B.W., HANLEY, S. and GOODMAN, H.M. (1992). Effects of ionizing radiation on a plant genome: analysis of two Arabidopsis transparent testa mutations. Plant Cel/4: 333-47.

SÖNNICHSEN, B., KOSKI, L.B., WALSH, A., MARSCHALL, P., NEUMANN B., BREHM, M., ALLEAUME, A.M., ARTELT, J., BETTENCOURT, P., CASSIN, E., et al. (2005). Full-genome RNAi profiling of early embryogenesis in Caenorhabditis elegans. Nature 434: 462-69. 
SPIEGELMAN, J.I., MINDRINOS, M.N., FRANKHAUSER, C., RICHARDS, D., LUTES, J., CHORY, J. and OEFNER, P.J. (2000). Cloning of the Arabidopsis RSF1 gene by using a mapping strategy based on high-density DNA arrays and denaturing high-performance liquid chromatography. Plant Cel/12: 2485-98.

STEARN, W.T. (1995). Botanical Latin. David and Charles, Devon, U.K.

STURTEVANT, A.H. (1965) A History of Genetics, Harper and Rowe eds., New York.

SUMANAS, S. and LARSON, J.D. (2002). Morpholino phosphorodiamidate oligonucleotides in zebrafish: a recipe for functional genomics? Brief Funct Genomic Proteomic 1: 239-56.

TAKADA, S., and GOTO, K. (2003). TERMINAL FLOWER2, an Arabidopsis homolog of HETEROCHROMATIN PROTEIN1, counteracts the activation of FLOWERING LOCUS T by CONSTANS in the vascular tissues of leaves to regulate flowering time. Plant Cel/15: 2856-65.

TSIANTIS, M., SCHNEEBERGER, R., GOLZ, J.F., FREELING, M. and LANGDALE, J.A. (1999). The maize rough sheath2 gene and leaf development programs in monocot and dicot plants. Science 284: 154-6.

TSUGE, T., TSUKAYA, H. and UCHIMIYA, H. (1996). Two independent and polarized processes of cell elongation regulate leaf blade expansion in Arabidopsis thaliana (L.) Heynh. Development 122: 1589-600.

TSUKAYA, H. (2003). Organ shape and size: a lesson from studies of leaf morphogenesis. Curr Opin Plant Bio/6: 57-62.

TSUKAYA, H. (2005). Leaf shape: genetic controls and environmental factors. Int $J$ Dev Bio/49: 547-55.

TSUKAYA, H. (2006). Mechanism of leaf-shape determination. Annu Rev Plant Biol 57: 477-96.

WADDINGTON, C.H. (1940). The genetic control of wing development in Drosophila. J Genet 41: 75-139.

WAITES, R., SELVADURAI, H.R., OLIVER, I.R. and HUDSON, A. (1998). The PHANTASTICA gene encodes a MYB transcription factor involved in growth and dorsoventrality of lateral organs in Antirrhinum. Cel/93: 779-89.

WANG, M. and STERNBERG, P.W. (2001). Pattern formation during C. elegans vulval induction. Curr Top Dev Bio/51: 189-220.

WEIGEL, D. and MEYEROWITZ, E.M. (1994). The ABCs of floral homeotic genes. Cel/78: 203-9.

\section{Further Related Reading, published previously in the Int. J. Dev. Biol.}

See our recent Special Issue Fertilization, in honor of David L. Garbers and edited by Paul M. Wassarman and Victor D. Vacquier at:

http://www.ijdb.ehu.es/web/contents.php?vol=52\&issue=5-6

See our recent Special Issue Plant Development edited by José Luis Micol and Miguel Angel Blázquez at:

http://www.ijdb.ehu.es/web/contents.php?vol=49\&issue=5-6

Preface - Plants develop and grow.

José L. Micol and Miguel A. Blázquez.

Int. J. Dev. Biol. (2005) 49: 449-452

Historical perspectives on plant developmental biology.

Mieke Van Lijsebettens and Marc Van Montagu.

Int. J. Dev. Biol. (2005) 49: 453-465

Balance between cell division and differentiation during plant development. Elena Ramirez-Parra, Bénédicte Desvoyes and Crisanto Gutierrez.

Int. J. Dev. Biol. (2005) 49: 467-477

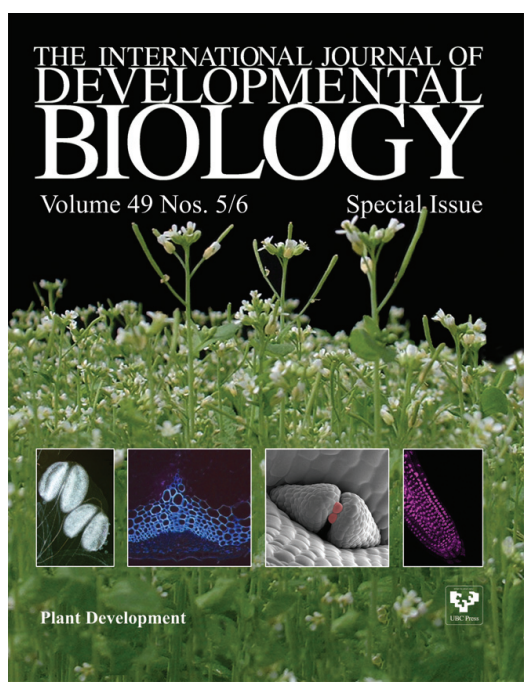

5 yr ISI Impact Factor $(2008)=3.271$

Plant microRNAs and development.

Sara Jover-Gil, Héctor Candela and María-Rosa Ponce.

Int. J. Dev. Biol. (2005) 49: 733-744

The development of concepts on development-a dialogue with Antonio García-Bellido.

Enrique Cerdá-Olmedo.

Int. J. Dev. Biol. (1998) 42: 233-236

\section{Seven types of pleiotropy.}

J Hodgkin.

Int. J. Dev. Biol. (1998) 42: 501-505

Syntagms in development and evolution.

F Huang.

Int. J. Dev. Biol. (1998) 42: 487-494

The genetic logic of Antonio García-Bellido.

G A Dover.

Int. J. Dev. Biol. (1998) 42: 535-538

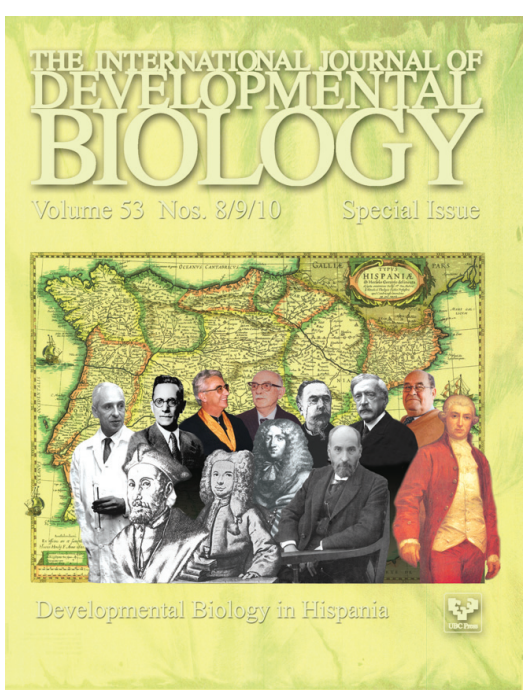

